\title{
分析化学と農 学
}

\section{不 破 敬 一 郎 東京大学農学部}

農学に括ける分析化学の占める位置について意見を申 し述べることが，私に与えられたテーマである．農学部 に参加させていただいて間もないので，まったく新参者 の意見である点を御容赦いただきたい。もっとも，この ことは私にとってたいへん大切な問題であるので常に考 えて抒り，たとえば毎年分析化学 I の講義をした後で, 「農学に括ける分析化学の重要性について論ぜよ」とい ら類の問いを，学年末の試験問題のなかに入れることに している. 学生には講義で聞かなかったような自分の考 えを述べるように注意を与兄，答案を読みながら新しい アイディアはないかと勉強している.

分析化学という分野は, 化学の始まりの分野であり, 方法を与克るたいへんに地味な分野である. その基本に 特いては現在とい党ども同じであるが，とり扱う範囲， 方法の多様化の故に，昔とはだいぶ様相が異なってきて いる. 農学といら分野に対する定義も, 御承知のごとく きわめてさまざまであり，これまた歴史が古いだけに複 雑なものとなっていて，大学内の一学部としてはきわめ てニニークな内容を持っている. 大学改革問題に関連し て, 農学のあり方ということについて否応なしに考光さ せられる機会があったわけであるが，これは範囲もより 広く、私がとやかく申すのるつつしむべきであると思う ので，分析化学の問題点を中心にして私見を述べさせて いただくことにする。

\section{昔と今の分析化学}

18 世紀の半ばに，ラヴォア・ジェが“燃焼とは可燃性物 質と酸素との結合である”ことを証明して近代化学がス タートした，との証明は，燃焼の前後に特ける物質の自 方を正しく測定し，灰となった事後の活らが，酸素の分 だけ事前より重くなって㜿り，それまで考兄られていた
フロジストンが抜け出て軽い灰になったのではないこと がわかった. 物の量を正しく計る分析化学のスタートで あある. その後, 多くの元素種が天然に拈いて取り出さ れ, 検出される過程に沶いて, 分析化学は無機化学に密 接につながった形で発展し, 炭素を中心に元素種の少な い有機化学は別に独立して一つの分野を形成した. 前者 の分野が単なる現象の記載のみにあきたらず, 理論化学 ないしは物理化学をつくり出し, 後者の分野が生物化学 をとり扱うようになって，第二次大戦の以前, すなわち われわれが学生として化学の勉強をしていたころの, い

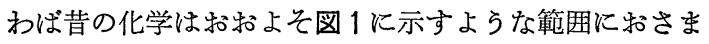
っていたように思う.

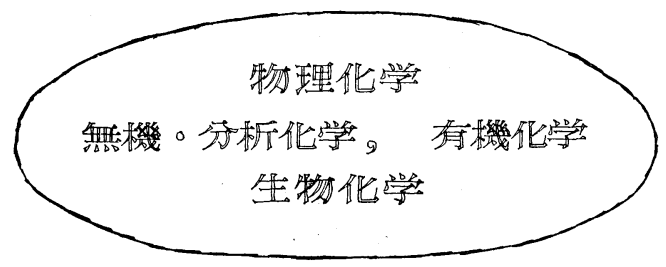

図 1 昔の化学の範囲

図 1 に示した範囲に挌汗る分析化学は, いわゆる古典 的な分析化学であり, 岩石鉱物を熔融して分離し, 沈澱 をつくって重量を計る，または滴定を行なって含有金属 量を求めるといら類のものでめり， C, H, N の元素分析 は，有機化学のなかで行なっていた。 それがここ 20〜 30 年間ではなはだしく変化した，対象に同位体元素， 放射性元素が入って細分されると同時に，無機有機の分 子種, ラジカルを測定し, さらにその結合状態, 存在状 態をもとめることまで分析化学の範囲に入れられた。い わゆる学際領域の科学の著しい発展のために, 化学气れ 自体は, 他の隣接分野, たとえば天文学, 地質学, 海洋 学, 医学, 農学, 生物学, 工学などとさわめて交流が密 接となり、ないしはそれらの分野のなかにむしろ完全に 


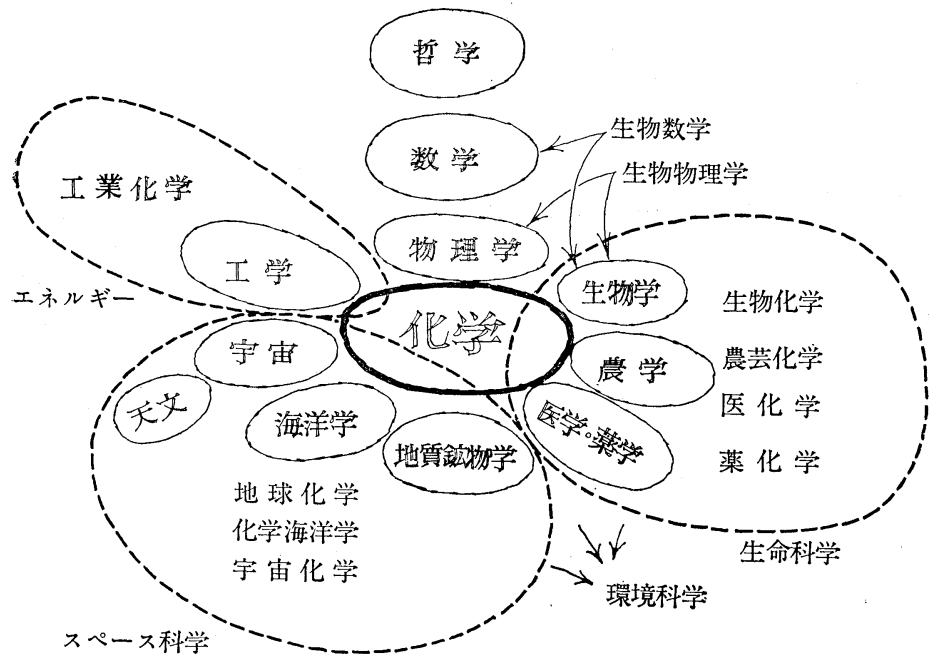

図 2 今日の化学の臨界領域

吸収されるという様相を示してきた，そのようすを模式 的に示すと図 2 のようになる。

この図はもちろん充分なるのとは思われないが，各分 野の境界線がいかになくなり，互いにはげしく接触が行 なわれて臨界領域の学問または統合的学問分野が，いた るところで発展してきた過程を示そうとしているもので ある，その間にあって，「物質」をとり扱ら化学が，自 然科学のすべての部分で基礎的役割を果たすこととなっ たのは当然であり，そしてその化学のなかで最も基本的 な方法を提供する分析化学一七年近代的に発展した分 析法一一が，いたるところで必要とされ，特の招のの近 代的発展の手段となる運命に立ち至ったのは，これまた 歴史的必然であったとい方よう。

外部からの要請により，分析化学が時代に応じた脱皮 を余儀なくされると同時に，分析化学自体の手法も大き く変化した．古典的な時間のかかる名人芸的な方法の代 りに, 速くて誰にでもできる機器分析法が急速に発展し た. 各種分光学的方法, 一連のカラム法, 電気化学的方 法などであり，それはめまぐるしく開発されて，さまざ まな要求に応兄，上記のごときぼう大な範囲をカバーす るに至った。一例をあげるならば，分子生物学の革命的 な発見の内容を検討すれば，インシュリンのアミノ酸組 成の決定のごとく，その一つ一つが分析的手法の積みか さねから得られた“化学的”結論であるといってよいで あろう。

ここに一つの困難と当惑が生じた．従来，分析化学者 をもって任じていた人たちが，とうていすべてをマスタ
一しきれないような質量両面の分析 技術の進展にいかにして対処したら よいかということである。一面から 見るならば誠に喜ぶべきこの分野の 発展であるが，個々の分析化学者は そのはげしい変化の故にとり残され て，何をしてよいかわからなくなり， 果ては “分析化学”とは一体, 現在 いかなる学問を指すのであるかを真 剣に考皇なければならない，しかも その結果の答は容易に得られない， という括かしな状態に遭遇するので ある.アメリカ化学会東北支部会の 会合の席上で，しばしば分析化学の 近代的教育法の論義が行なわれ，分析化学がきわめて実 社会で有用であるにもかかわらず; 学生が興味を示さな いのをいかにして正すべきか，について意見がたたかわ された. MIT の分析担当の Hume 教授は，この混乱 状態を，“分析化学者”之呼ばれる者を次のように定義 づけることにより明らかにしようとした；

A good practical description of the modern professional analytical chemist is one who is a specialist in the methodology of solving problems having to do with the properties of chemical systems.

ここに抒いて, Hume 教授は, "highly educated specialist”としての analytical chemist を定義しよう としたのであり，それと分析者，“trained technician” との区別をはっきりさせることの必要性を強調している. つまり，人々のイメージにきざまれている昔の分析化学 者は，自ら白衣を着てルッボを扱い，沈澱をつくって重 量分析をコシコッと行なっている人であったのであるが， それは現代では通用しないとしている，実際の分析に手 をくだして行なうのは technician の仕事であって， analytical chemist の仕事ではない. analytical chemist は, いかなる分野にあっても化学に関与した問題が生じ たときに，それを解決する手段を考光出し，組合せ，全 体のプランをたてる専門家であるべきなのである、そし て彼は，その問題解決の方法をつくることに興味を感ず るのであって, 方法ができ上り，これが用いられて出て きた結果についてはるはや興味を示さないというのが一 つの特徴である. 
この意見はきわめて興味深い，たぶん反論が多く起こ るであろらけれども，そしてたぶん国情によっても事情 は多少異なるであるうけれども，既述したごとき複雑化 した現代分析化学の専門家に要求されるべきことは, 事 実上，否応にかかわらず，Hume 氏の定義に近いものと なっているのである.

\section{大学における分析化学}

化学それ自体も最近影がうすくなったといわれる。そ してそのなかで 4 半世紀にわたって分析化学のたどった 革命的な变化は，特执よそ上記のごとくであった．私自 身はこの間をハーバード大学医学部の一室に和いてすご し，変化はたしかに身近かに感じた．今ふり返ってみる と，それがより明らか感じられる。米国内の大学に持 いて，分析化学の講座の姿が見えなくなるという現象が 起こった，それは物理化学のなかに吸収された，手法が 極度に物理的，機器的になったこととすすべての分野に 拡散して吸収されたことの当然の帰結であったといえよ う.しかし，それは分析化学の重要性が減少したのでは なく，むしろ逆に増加したが故であることはすすでに読 者の皆さんには招わかりいただけると思う。

やがてその反動は現われ出した.メーターの読みだけ を見ていたのでは正確な化学分析を期待することはでき ない，古典的な純粋物質のとり扱いに基礎を执いた現代 的な機器分析化学こそが大切なのである. そして，分析 化学の研究室がふたたび新しい姿で米国の大学に現われ だした. ヨーロッパも例外ではなかった。

東京大学農学部農芸化学科のなかに分析化学の講座が 新設されたのも，まさにこの時期である，お国柄はいろ いろであるから，この講座新設の直接の理由は扔そらく さまざまであり，もっと現実的な事態の故であったのか もしれないが，背後には国境を越えて共通したこの分野 に対する有形無形の要請があった故であろうと信じてい る.私の興味の中心であった生物体の金属の analytical biochemistry は, 日本ではとてもできないであろうから， 私は帰国することは考えていなかった，それだからこの 農学部の分析化学講座新設のことをうかがったときた いんびっくりした． 数年前のそのときの驚きをよく記 憶している.上述の分析化学の変革の歷史が一瞬に頭に 走りすぎて，やはり東京にもできたのだなという気持が した。特和げさないい方をすれば，忘れていた祖国にと
って喜ばしいことだという思いが強くした，現在，私が この分析化学の講座に所属しているゆええである。

\section{農学と環境科学}

いわゆる “environment”が米国内で急に一般の人々 の関心を集めだしたのは，ジョンソンがケネディーの残 りの任期終了後，改めて大統領に選ばれた直後であった と記憶する. ジョンソン夫人が熱心で, “Keep America Beautiful”という標語を子供たちの間にはやらせた。

研究のターゲットが大きく移りかわり，学際領域が強 調されだしたことはすでに図 2 に示した. 米国がここで も強い影響力を持った，原子力，生命科学，スペース， 環境，そしてエネルギー問題と進行しつつあることは御 承知の通りである.

米国内で農学部が環境科学と結びついて，名称を変兄 てしまった例が目につく、ラトガース大，ミズーリ大な ぞである. 近年のいわゆる公害問題，そしてそれを拡張 した環境問題が，すべての自然科学の発展の所産であり, その範囲の広さ之根源の深さは人類の歴史そのものの広 さと深さに相当するるのである，したがって，諸分野か らこれをとらえることができるわけであるが，地球表面 の土壌に根を括ろし，人とのつながりを持った農学は， やはりこの問題に最も密接な立場にあり，末たあるべき であるような気がする。

古典的な分析化学が，近代的分析化学への移行を余儀 なくされたのときわめて類似した対比が，古い伝統を持 った “農学”之現代の “環境科学”との間に存在するよ らに思われる。

\section{第 12 回ペプチド化学討論会}

とき昭和 49 年11月1日（金), 2 日（土）

ところ 京都教育文化センター

京都市左京区聖護院川原町 4-13

電話 (075) 771-4221 (京大病院正門前)

討論主題 1 １ペプチドの合成战よび反応（関連アミ ノ酸誘導体を含む)

2. 生理活性ペプチ,ドの化学 (分離，精製， 構造および合成)

講演申込等の詳細につきましては，下記にお間い合わせ ください（申込締切日は 8 月 31 日です）

于 606 京都市左京区吉田下阿達町 京都大学薬学部 矢島治明 宛 電話 (075) 751-2111 内線 4551 